\title{
Effect of Leadership Style and Organization on Employee Through Job Satisfaction (Empirical Study on Five Construction Companies in Indonesia)
}

\author{
Meina Woro Kustinah \\ Departement of Management \\ Trisakti University \\ Jakarta, Indonesia \\ meina.usakti@gmail.com
}

\author{
Iman Indrati \\ Departement of Management \\ Trisakti University \\ Jakarta, Indonesia \\ pecalangbali@yahoo.com
}

\author{
Erny Tajib \\ Departement of Management \\ Trisakti University \\ Jakarta, Indonesia \\ ernytajib@trisakti.ac.id
}

\begin{abstract}
The success of the job depends on the level of performance of each company which supported by workers contribution. Certainly the fruitfulness is influenced by leadership style, organizational communication and job satisfaction that can enhance worker performance. The purpose of this research is to verify; Is there any influence of leadership style on job satisfaction, the influence of organizational communication on job satisfaction, the influence of leadership style on employee performance, the influence of organizational communication on employee performance, the impact of job satisfaction on employee performance in handling construction work. Furthermore, whether job satisfaction is able to mediate the influence of leadership style on employee performance and job satisfaction able to mediate the influence of organizational communication on employee performance. The results of hypothesis examination: leadership style influences job satisfaction of workers, organizational communication influences job satisfaction of workers, leadership style influences employee performance, organizational communication influences employee performance, job satisfaction affects employee performance. Furthermore, it is verified that job satisfaction is able to mediate the influence of leadership style on employee performance, and job satisfaction able to mediate the influence of organizational communication on employee performance of construction companies.
\end{abstract}

Keywords: Leadership Style, Organizational Communicaation, Job Satisfaction, Employee Performance

\section{INTRODUCTION}

The Directorate of Water Supply System Development under the Directorate General of Cipta Karya, the Ministry of Public Work and Housing has a function to provide drinking water supply facilities in Indonesia. In carrying out the project work for the Development of Water Supply Systems, the Ministry of Public Works and Public Housing uses the services of a construction company as a supporting contractor for its implementation. The result quality of the project done by the contractor is also varies from good to bad. The success of this work depends on the level of performance of the workers. Workers are required to have high performance, given the success of physical activities (construction), handled responsibly for their success.

Human Resources are the key to the success of a project, therefore we must recruit experts and create a good working environment for a good work culture to increase work motivation. However, research in examining the role of leadership style and communication (organizational communication) to improve the quality of human resources, especially in construction companies in Indonesia is very rarely found, so this study was conducted by taking case studies of the construction company organization within the environment of Directorate General Cipta Karya work unit, Ministry of Public Work and Housing (PUPR).

Leadership in the context of construction industry has a key role because field work is a quite complex work where various aspects are involved in the project (Markiz, 2017).[1] In addition to leadership styles which have a big role to play in the success of construction companies in handling construction work, Hidayah (2012) highlights that inefficient communication can also triggers low work performance, financial claims, security and inefficiencies.[2] Good communication is one of the interpersonal competencies that play an important role in the success of doing construction work. Other research shows that project supervisors must intensively communicate and convey any information to ensure that workers do their work based on standards to avoid problems. The company's demands to obtain, develop and maintain quality resources are increasing to fulfill national infrastructure and technology development. The quality of the work of a worker is influenced by internal and external factors of the worker. Some of the factors that have influence toward it are the influence of the leadership style on the work team, the level of quality and comfort in communication (organizational communication), and job satisfaction perceived by the worker.

\section{A. Leadership style}

According to Sunarcaya (2008) leadership style is an attitude of how to control subordinates to carry out a job.[3] Regina (2010) states that leadership style is behavior and strategy as a result of a combination of philosophy, skills, traits, attitudes of a leader when trying to influence the subordinate's leadership style.[4] It can be concluded that leadership style is how a leader directs others to achieve a goal. In his book Lessons in Library Leadership: A Primer for 
Library Managers and Unit Leaders, Halaychik (2016) explains that there are several types of leadership styles, namely:[5]

\section{1) Autocratic style}

Autocratic or authoritarian leadership is categorized by the behavior of a leader exercising complete control and almost exclusively making decisions without input from followers. Individuals who like this form of leadership are task-oriented, happy to be responsible, comfortable directing the work of others, and having high confidence making good decisions.

\section{2) Participatory style}

Participatory Leadership Style, a leader actively engages followers in the decision making process. This is achieved by taking a democratic approach to find a way forward. An individual using this approach understands that they are still responsible for deciding an action and collecting feedback and suggestions for alternatives.

\section{3) Delegative Style}

Delegative leadership, also often referred to as LaissezFaire leadership, is characterized by the behavior of a leader who rarely interferes with subordinate affairs. The delegative style effectively requires a leader who has full power.

\section{4) Situational Style}

The Situational Leadership Style takes the approach that there is no one method of leadership that is suitable for all situations. This leadership style behavior can be achieved by evaluating situational situations.

\section{B. Organizational Communication}

Organizational communication is a form of exchanging messages between communication units within a particular organization. The organization itself consists of communication units in hierarchical relationships between one another and functions in an environment. Organizational communication involves humans as subjects involved in the process of receiving, interpreting and acting on information. Communication is a process that connects individuals and groups within an organization or society by creating, sending and using information to coordinate among organizational members (Pamungkas, 2016).[6]

Communication is the process of someone interactively creating, maintaining, and managing meaningful messages (Adriansyah, 2016).[7] Communication is also an interaction maintained between individuals or groups where information is sent to the recipient to be understood. In addition, communication is also able to create, maintain and regulate certain messages in a society. Organizational communication is the exchange of information in a group that members share interdependent relationships to deal with certain situations (Rai, 2015). [8] In the context of construction work, Markiz, et al (2017) effective communication is very important to maintain teamwork and coordination between workers and used to motivate workers to work well in accordance with the statement in the contract. The failure of the construction industry is strongly influenced by ineffective communication. One factor that triggers ineffective communication is the fact that construction projects are temporary projects with limited time. In general, organizational communication is divided into three main dimensions; (1) communication with colleagues,
(2) communication with managers and (3) organizational communication policies. There is a lot of literature about organizational communication.[9]

\section{Job Statisfaction}

Job satisfaction, a concept that is widely studied in organizational behavior research, is generally conceptualized as an effective variable that results from an assessment of individual work experience. Job satisfaction is a key factor in carrying out construction work because it is the link between managerial staff and employees which is important for project supervisors to determine wages for employees (Kristianto, 2013).[10] Measurement of job satisfaction in the construction sector adopts the theory of job satisfaction where job satisfaction is seen as a match between what is expected and what is experienced when doing a particular job. Job satisfaction also refers to positive or negative feelings from an employee towards his work (Dewi, 2015).[11] Work requires interaction with colleagues and superiors, adheres to organizational rules and policies, meets performance standards and lives with an ideal work atmosphere. Job satisfaction is a general attitude of individuals towards their work so that it reflects more attitudes than behavior. Schermerhorn, (2008) introduces five aspects of job satisfaction as well as measured by Job Descriptive Index, popular questionnaires: (1) Work itself - responsibility, interest and growth, (2) quality supervision - technical and social support support, (3) relationships with colleagues social harmony and respect, (4) promotion opportunities opportunities for further progress and (5) pay - adequacy of payment and perception of fairness compared to peers.[12]

Job satisfaction in work is a satisfaction feeling that is enjoyed at work by gaining praise for work, placement, treatment, equipment, and a good working environment. Employees who prefer to enjoy job satisfaction at work prioritize their work rather than reciprocate even though the remuneration is important. Satisfaction outside work is employee job satisfaction that is enjoyed in work outside work with the amount of remuneration from his work.

\section{Employee Performance}

Performance becomes a warm topic among decision makers who always highlight how the staff or employees perform. Performance comes from the word employee performance or actual performance which means work performance or actual achievement achieved by someone. To determine the performance of employees, it is necessary to assess the performance itself, from the assessment can be known whether the performance produced by employees has met the standards or not. The definition of work performance is a work of a worker, an overall organizational management process, in which the results of the work must be shown concretely and can be measured.

Employee performance is defined as the total expected value for an organization from episodes of individual discrete behavior over a standard time period (Motowildo and Kell, 2012).[13] Jalagat (2016) mentions several factors that affect employee job performance, namely; 1) attitude and mentality (motivation, discipline, ethics), 2) education, 3) skills, 4) leadership management, 5) income level, 6) salary and health, 7) insurance, 8) work environment, 9) facilities, 10) 
technology, and 11) career paths. Construction work requires many people, a long process, various steps, and supervision from the public sector and the non-government sector to bring the project to a success. Measurements on the performance of certain construction projects help managers to provide continuous feedback during operational activities.[14]

In conclusion, employee's work performance is the result of work achieved by a person in carrying out tasks based on ability, experience, and patience also on time. The reason for evaluating work performance against subordinates is: 1). Assessment must play an integrated role in the project work performance management process, 2). Assessment of superiors and subordinates develop plans to assess all deficiencies in the assessment. 3). Assessment must serve career planning purposes by providing an opportunity to review by observing specific strengths and weaknesses.

\section{E. Research Questions}

1) Does the leadership style affect job satisfaction of construction company workers?

2) Does organizational communication affect job satisfaction of construction company workers?

3) Does the leadership style affect the company's performance in handling construction company work?

4) Does organizational communication affect the company's performance in handling construction company work?

5) Does job satisfaction affect the company's performance in handling construction company work? (6) Is job satisfaction able to mediate the influence of leadership style on the company's performance in handling construction company work?

6) Is job satisfaction able to mediate the influence of organizational communication on the company's performance in handling construction company work?

\section{METHODS}

This study uses quantitative methods. We use primary data obtained directly from respondents as sources of data in this study. The data was collected by questionnaire technique, namely by giving written questions to respondents. The study uses a testing instrument to measure the reliability and validity of the measured instrument. We use data processing by LISREL 8.80 software from Structural Equation Modeling (SEM) to test the hypothesis.

\section{FINDING AND DISCUSSION}

The following is a table showing the results of processing descriptive statistics. Descriptive statistics are more related to collecting, summarizing, presenting and describing data so that it can provide useful information. The data presented in descriptive statistics are usually in the form of: Data center size, such as mean, median and mode. Size of data dissemination, such as standard deviation and variance. The size of the data form, which is the symmetry of the shape and tangle of a distribution.
Table 1.

Descriptive statistical of all variables

\begin{tabular}{cccccc}
\hline Variable & $\mathrm{N}$ & $\begin{array}{c}\text { Mini } \\
\text { mum }\end{array}$ & $\begin{array}{c}\text { Maxi } \\
\text { mum }\end{array}$ & Mean & $\begin{array}{c}\text { Std. } \\
\text { Deviation }\end{array}$ \\
\hline Leadership Style & 162 & 3.00 & 4.00 & 3.4116 & 0.42861 \\
$\begin{array}{c}\text { Organizational } \\
\text { Communication }\end{array}$ & 162 & 2.92 & 4.00 & 3.3554 & 0.41871 \\
$\begin{array}{c}\text { Job Satisfaction } \\
\text { Employee }\end{array}$ & 162 & 2.42 & 4.00 & 3.2854 & 0.39360 \\
Performance & 162 & 3.00 & 4.00 & 3.3783 & 0.46416 \\
\hline
\end{tabular}

Source: SPSS output

Table 1 shows the Leadership Style variable obtained by the mean value of 3.4116 with a minimum value of 3 and a maximum value of 4 , meaning that the respondence feel that the leader shares his thoughts, ideas and opinions with others, the leader participates as someone who is equal in his group, the leader ensures employees have the resources / the ability they can do to work, and the leader provides direction and makes all decisions; with the deviation of the respondent's answer to the average (standard deviation) of 0.42861 .

The Organizational Communication variables obtained by the mean value of 3.3554 with a minimum value of 2.92 and a maximum value of 4 , meaning that the respondence agreed that when carrying out a task or job their superior was always gave an instructions, agreed that in carrying out their task there must be a coordination between department, agreed that the boss gave a warning to colleagues who made mistakes, and feel satisfied that they had had the opportunity to submit suggestions and ideas for the progress of the company; with the deviation of the respondent's answer to the average (standard deviation) of 0.41871 .

In the Job Satisfaction variable, the mean value is 3.2854 with a minimum value of 2.42 and a maximum value of 4 , meaning that the respondence feel that the leader is willing to listen to aspirations, the leader provides support, the leader provides clear direction, co-workers share knowledge and information when working, and mutual intimacy co-workers are excited about working; with the deviation of the respondence's answer to the average (standard deviation) of 0.39360 . The employee performance variable obtained the mean value of 3.3783 with a minimum value of 3 and a maximum value of 4 , meaning that the respondence feel that being able to work deftly, quickly and precisely to the new assignment given, developing and using technical knowledge at work could identify the root causes of the problem. complicated, and trying to improve the work process; with the deviation of the respondent's answer to the average (standard deviation) of 0.46416 .

Data analysis is obtained from the results of testing the hypothesis. The purpose of testing the hypothesis is to find out whether the Ha hypothesis tested is accepted or rejected. This can be seen by looking at the t values (1.96) of each hypothesis test result. As for the fault tolerance limit $(\alpha)$ the acceptance and rejection of the hypothesis is $5 \%$. If $t$ values 
(1.96) $>t$ count then there is a significant effect of variable $x$ on variable $y$.

In this study, the author uses the help of LISREL 8.80 software to test the research hypothesis. The SEM test results can be seen from three LISREL 8.80 output images, namely Estimates, Standardized Solution and T Values. The following is a picture with LISREL 8.80 output:

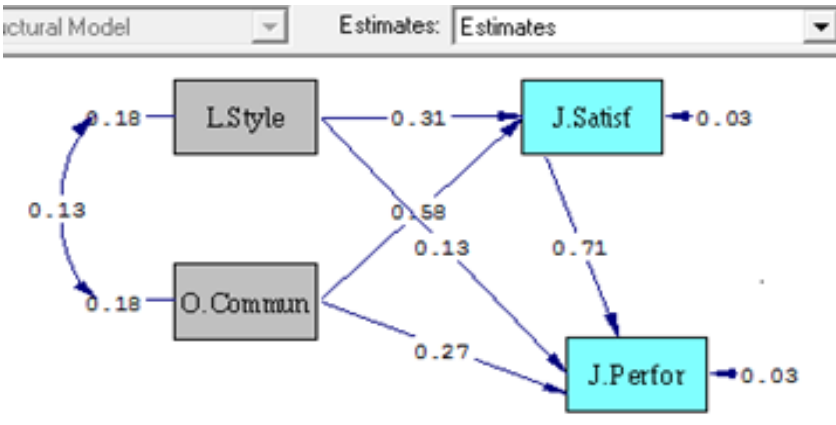

Figure 1. Structural Model (Estimates)

Source: Processing Results with LISREL 8.80

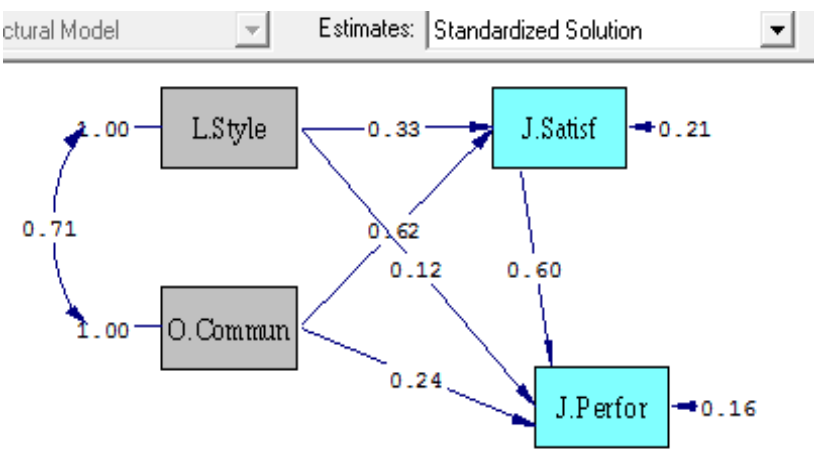

Figure 2. Structural Model (Standardized Solutions) Source: Processing Results with LISREL 8.80

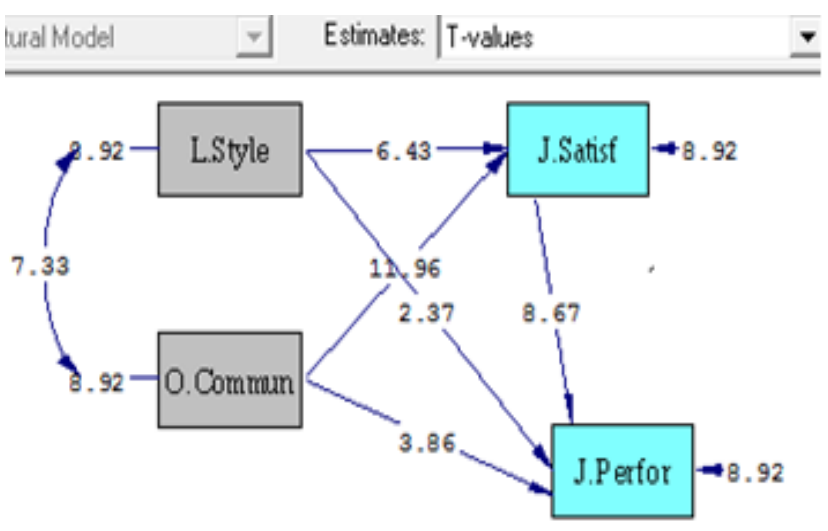

Figure 3. Structural Model (T Values)

Source: Processing Results with LISREL 8.8

The results of data analysis with LISREL 8.80 are presented in the following table form:
Table 2. Results of regressive calculation by SEM LISREL

\begin{tabular}{|c|l|c|c|c|c|}
\hline No. & $\begin{array}{l}\text { Regression } \\
\text { relation }\end{array}$ & $\beta$ & $\begin{array}{c}\mathrm{T} \\
\text { Values }\end{array}$ & Criteria & Information \\
\hline $\mathrm{H}_{1}$ & $\begin{array}{l}\text { Leadership style - } \\
\text { > Job satisfaction }\end{array}$ & 0.31 & 6.43 & $>1.96$ & $\mathrm{H}_{1}$ suported \\
\hline $\mathrm{H}_{2}$ & $\begin{array}{l}\text { Organizational } \\
\text { communication - } \\
\text { > Job satisfaction }\end{array}$ & 0.58 & 11.67 & $>1.96$ & $\mathrm{H}_{2}$ suported \\
\hline $\mathrm{H}_{3}$ & $\begin{array}{l}\text { Leadership style - } \\
\text { > Employee } \\
\text { Performance. }\end{array}$ & 0.13 & 2.37 & $>1.96$ & $\mathrm{H}_{3}$ suported \\
\hline $\mathrm{H}_{4}$ & $\begin{array}{l}\text { Organizational } \\
\text { communication - } \\
\text { > Employee } \\
\text { Performance. }\end{array}$ & 0.27 & 3.86 & $>1.96$ & $\mathrm{H}_{4}$ suported \\
\hline $\mathrm{H}_{5}$ & $\begin{array}{l}\text { Job satisfaction - } \\
\text { > Employee } \\
\text { Performance. }\end{array}$ & 0.71 & 8.67 & $>1.96$ & $\mathrm{H}_{5}$ suported \\
\hline $\mathrm{H}_{6}$ & $\begin{array}{l}\text { Leadership style } \\
\rightarrow \text { Job } \\
\text { satisfaction } \rightarrow \\
\text { Employee } \\
\text { performance }\end{array}$ & 0.22 & 5.16 & $>1.96$ & $\mathrm{H}_{6}$ suported \\
\hline $\mathrm{H}_{7}$ & $\begin{array}{l}\text { Organizational } \\
\text { communication } \\
\rightarrow \text { Job } \\
\text { satisfaction } \rightarrow \\
\text { Employee } \\
\text { performance }\end{array}$ & 0.41 & 7.02 & $>1.96$ & $\mathrm{H}_{7}$ suported \\
\hline
\end{tabular}

Source: SPSS output

\section{Results of hypothesis testing:}

1. Hypothesis 1: Leadership style influences job satisfaction of construction company workers. Based on the results of data analysis it is known that the value of $t=6.43$, and the value of $\mathrm{t}>1.96$ then $\mathrm{h} 1$ is accepted, which means there is a significant influence of Leadership style on Job satisfaction. Referring to the beta coefficient $(\beta)=0.31$, the higher / better the leadership style, the more high / good Job satisfaction, on the contrary the lower / worse Leadership style, the lower / worse Job satisfaction of construction company workers.

2. Hypothesis 2: Organizational communication affects job satisfaction of construction company workers. Based on the results of data analysis it is known that the value of $t=$ 11.67 and the value of $t>1.96$ then $h 1$ is accepted, which means that there is a significant effect of Organizational Communication on Job Satisfaction. Referring to the beta coefficient $(\beta)=0.58$. then the higher / better Organizational communication, the higher / better Job Satisfaction, on the contrary the lower / worse Organizational Communication, the lower / worse Job Satisfaction of construction company workers.

3. Hypothesis 3: Leadership style influences employee performance of construction company workers. Based on the results of data analysis it is known that the value of $t=2.37$ and the value of $\mathrm{t}>1.96$ then $\mathrm{h} 1$ is accepted, which means that there is a significant effect of Leadership style on employee performance. Referring to the coefficient beta $(\beta)=0.13$, the higher / better Leadership style, the higher the employee performance, the lower the poorer Leadership style, the lower the employee performance of the construction company.

4. Hypothesis 4: Organizational communication influences employee performance of construction company workers. Based on the results of data analysis it is known that 
the value of $t=3.86$ and the value of $t>1.96 \mathrm{~h} 1$ is accepted, which means that there is a significant influence of Organizational communication on employee performance. Referring to the coefficient beta $(\beta)=0.27$, the higher / better Organizational communication, the higher the employee performance, the lower the Organizational communication, the lower the employee performance of the construction company.

5. Hypothesis 5: Job satisfaction affects employee performance of construction company workers. Based on the results of data analysis it is known that the value of $t=8.67$ and the value of $t>1.96$ then $h 1$ is accepted, which means there is a significant influence Job satisfaction on employee performance. Referring to the coefficient beta $(\beta)=0.71$, the higher / better Job satisfaction, the higher the employee performance, the lower the job satisfaction, the lower the employee performance of the construction company employee.

6. Hypothesis 6: Job satisfaction is able to mediate the influence of leadership style on employee performance of construction company workers. Based on the results of data analysis it is known that leadership style influences on employee performance mediated by job satisfaction with $t$ count of 5.16 (5.16>1.96), therefore it can be concluded that H6 is accepted, which means Job satisfaction is able to mediate the influence of leadership style on employee performance construction company.

7. Hypothesis 7: Job satisfaction is able to mediate the influence of organizational communication on employee performance of construction companies. Based on the results of data analysis, it was found that Motivation's effect on Performance Employees mediated by Job Satisfaction with $t$ count was 7.02 (7.02> 1.96), therefore it can be concluded that $\mathrm{H} 7$ is accepted, which means job satisfaction is able to mediate organizational communication against employee performance of construction companies.

Based on the results obtained it is known that the findings of this research hypothesis test have similarities with the research hypothesis proposed and based on the findings of the journal referred to. Leadership style influences job satisfaction and leadership styles affect employee performance. Leadership has a function to guide employees to behave in certain ways to achieve job satisfaction and organizational commitment. In addition, leadership style has a significant influence on employee job satisfaction. Leadership plays an important role in construction companies to improve better performance. the strength of the influence of leadership style on project success depends on the characteristics of the industrial sector and the type of project. Leadership is an important factor in the management of construction companies because leadership does not only manage projects but also art to influence the behavior of others to achieve certain goals.

Organizational communication affects job satisfaction and organizational communication influences employee performance. Organizational communication affects employee job satisfaction. Communication can improve employee satisfaction. Effective internal communication stimulates increased job satisfaction and provides better competitiveness and competency organizations. Communication represents people's minds that can be used to influence the minds of others. Organizational communication can positively influence job performance, besides effective communication is maintained in problem solving projects in teams which also show that communication can improve job performance for employees.

Job satisfaction affects employee performance. Job satisfaction has a certain influence on the job performance of professional salesmen, where job satisfaction has a positive effect on job performance. Other research shows that job satisfaction has a certain influence on work performance. This can happen because job satisfaction is a person's evaluation of fairness in doing certain jobs, making satisfaction not only supports better performance, but also makes them feel high citizen organizational behavior

Job satisfaction is able to mediate the influence of leadership style on employee performance and job satisfaction can mediate the influence of organizational communication on employee performance. Leadership can influence teamwork with good competency support, apprenticeship satisfaction and formalization of organizations which show that leadership can influence job performance through the role of other variables. The findings of this study also confirm that job satisfaction is a mediating variable between the influence of organizational communication on job performance, where effective communication stimulates higher job satisfaction that also supports competitiveness and better organizational competency.

\section{CONCLUSION}

Based on the results of hypothesis testing, therefore it is known: leadership style influences job satisfaction of construction company workers, organizational communication influences job satisfaction of workers, leadership style influences employee performance, organizational communication influences employee performance, job satisfaction influences employee performance, job satisfaction is able to mediate influence leadership style on employee performance and job satisfaction can mediate the influence of organizational communication on employee performance of construction companies.

From the results of the study, it is suggested that the construction companies need to take strategic steps to create positive factors to increase job satisfaction and employee performance, including: 1) understanding the vertical communication will influences organizational communication on job satisfaction because the employee would feel to have the opportunity to deliver suggestions and ideas for the sake of progress of the company, 2) understanding that leadership style has an effect on employee performance by diligently motivate and encourage the quality of work of their employees and participate, 3) understanding that organizational communication has an effect on employee's performance, because the employees will have positive and more quality relationships between the employees with their superior, 4) understanding that job satisfaction has an effect on employee performance because employees who have higher satisfaction levels will have the higher the spirit of work, 5) leadership style and organizational communication to improve employee performance can be done through job satisfaction mediation. 


\section{REFERENCES}

[1] Markiz, Yudiawan. The Influence of Leadership Styles, Organizational Communication, And Job Satisfaction Toward Employees' Job Performance In Doing. DOI. 2017.

[2] Hidayah. Dwimartha. The Effect of Organizational Communication on Employee Job Satisfaction and Its Implications for Organizational Commitment at the Directorate of Human Resources of PT Pos Indonesia (Persero), Bandung. 2012.

[3] Putu Sunarcaya. Analysis of Factors Affecting Employee Performance in Alor District Health Office East Nusa Tenggara. Thesis, Jakarta Open University. 2008.

[4] Regina (2010) Regina, (2010). The influence of leadership style, motivation and work discipline on employee performance at PT. Sinar Sentosa Perkasa Banjarnegara. Undergraduate Thesis. Diponegoro University.

[5] Halaychik, C. Lessons in Library Leadership 1st Edition A Primary for Library Managers and Unit Leaders. Chandos Publishing. 2016.

[6] Pamungkas, Satria. The Influence of Organizational Communication on Employee Job Satisfaction at PT Harpingo Jaya Yogyakarta. State Islamic University. Yogyakarta. 2016.

[7] Dimas Okta Ardiansyah (2016). The Influence of Communication on Employee Performance in Mediation by Job Satisfaction (Study in the Parts of Paper Factory Production of PT. Setia Kawan Makmur Sejahtera Tulungagung). Journal of Business and Management.
[8] D. I Gst Agung Rai, Cahyadi Putra, Ni Wayan Mujiati. Effect of Communication, Leadership and Compensation on Employee Satisfaction at PT. BPR Nusamba Mengwi. E Management Journal of Udayana University. 2015.

[9] Markiz, Yudiawan. (2017). The Influence Of Leadership Styles, Organizational Communication, And Job Satisfaction Toward Employees' Job Performance In Doing. DOI.

[10] Kristianto, Harris. Organizational Justice, Organizational Commitment, and Employe Performance. Journal of Management and Entrepreneurship: Vol. 17, No. 1. 2013.

[11] Dewi Kurniawati. The Influence of Communication on Employee Job Satisfaction at KPRIUniversitas Brawijaya Malang. 2008.

[12] Schermerhorn, J. R. Jr, Hunt, Richard N., Osborn. Organizational Behavior: 10th Edition. Willey. 2008.

[13] Motowildo S. J., Harrison J. Kell. Chapter 5 Job Performance. Handbook of psychology, vol. 12: Industrial and organizational psychology Edition: 2nd Chapter: Job performance Publisher: Wiley Editors: Neal W. Schmitt, Scott Highhouse. 2012.

[14] Van S Dalluay, Revenio C Jalagat. Impacts of Leadership Style Effectiveness of Managers and Department Heads to Employees' Job Satisfaction and Performance on Selected Small-Scale Businesses in Cavite, Philippines. International Journal of Recent Advances in Organizational Behavior and Decision Sciences. Jupiter Global Business Research FZE. 2016. 